\title{
Candesartan kan forebygge migrene
}

\section{Angiotensinreseptorblokkeren candesartan har god effekt som anfalls- profylakse hos pasienter med migrene. Dette viser to norske studier.}

Migreneforebyggende medisiner brukes for lite. Dette kan skyldes begrenset effekt, bivirkninger og kontraindikasjoner. Vår forskningsgruppe var den første som viste at angiotensinreseptorblokkeren candesartan er bedre enn placebo som migreneforebyggende medisin (1). Candesartan er etter dette blitt tatt i bruk mot migrene i mange land, til tross for at det ikke er blitt gjort studier som bekrefter effekten.

I en ny placebokontrollert studie har vi sammenliknet effekten av candesartan i 16 mg dosering som profylakse mot migreneanfall med propranolol, den mest brukte betablokkeren, i $160 \mathrm{mg}$ retardformulering, og med placebo (2). Både candesartan og propa-

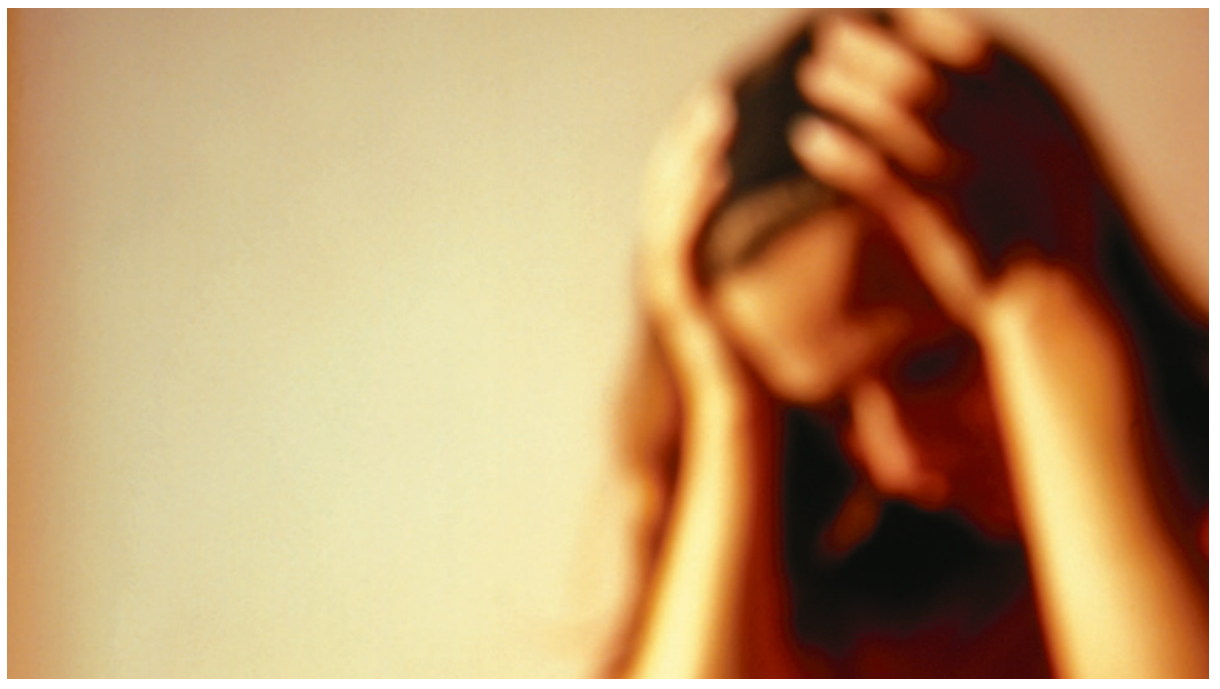

nolol var mer effektive enn placebo $(2,95$ (95\% KI 2,35-3,55) og 2,91 (2,36-3,45) versus $3,53(2,98-4,08)$ migrenedager per fire uker), og effekten av candesartan var ikke dårligere enn effekten av propranolol ved non-inferiority-analyse.

Candesartan tolereres generelt godt og har færre kontraindikasjoner enn betablokkere. I vår studie hadde noen av pasientene kun effekt av candesartan, mens andre kun hadde effekt av propranolol. I klinisk praksis har vi erfaring for at noen pasienter kan klare seg med en lavere dose candesartan $(8 \mathrm{mg})$ enn det vi har brukt i studiene (16 mg), mens enkelte må ha en høyere dose (24-32 mg) for å oppnå en reduksjon av migreneanfall. Vi mener at candesartan nå bør tas med i behandlingsretningslinjene for pasienter med relativt hyppige migreneanfall og at candesartan bør omfattes av blåreseptordningen.

\section{Lars Jacob Stovner}

Erling Tronvik

Nasjonal kompetansetjeneste for hodepine

St. Olavs hospital

\section{Litteratur}

1. Tronvik E, Stovner LJ, Helde G et al. Prophylactic treatment of migraine with an angiotensin II receptor blocker: a randomized controlled trial. JAMA 2003; 289: 65-9.

2. Stovner LJ, Linde M, Gravdahl GB et al. A comparative study of candesartan versus propranolol for migraine prophylaxis: A randomised, tripleblind, placebo-controlled, double cross-over study. Cephalalgia 2013; e-publisert 11.12.2013.

\section{Vaginal fødsel er tryggest ved sterke bekkenleddsmerter}

\section{Keisersnitt øker risikoen for vedvarende sterke bekkenledd- smerter etter fødsel sammen- liknet med vaginal fødsel.}

Keisersnittsratene øker. Dette kan i noen grad skyldes at kvinner i økende grad ønsker planlagt keisersnitt uten medisinsk eller obstetrisk indikasjon. Svangerskapsrelaterte bekkenleddsmerter er assosiert med ønske om og med økt forekomst av planlagt keisersnitt. Hvordan påvirker så keisersnitt prognosen ved bekkenleddsmerter? Vi har nylig undersøkt sammenhengen mellom forløsningsmetode og vedvarende bekkenleddsmerter seks måneder etter fødsel (1).

Studien omfattet flere enn 10400 kvinner i Den norske mor og barn-undersøkelsen som hadde rapportert om smerter over symfysen og begge iliosakralleddene (bekkenleddsyndrom) i svangerskapsuke 30. Vi benyttet spørreskjemadata fra svangerskapsuke 17 og 30 samt seks måneder etter fødsel. Datafilene ble koblet til Medisinsk fødselsregister.

Planlagte keisersnitt var assosiert med en nesten tredoblet risiko for pasientrapportert alvorlig bekkenleddsyndrom, definert som sterke smerter over alle bekkenleddene, seks måneder etter fødsel. Hos kvinner som brukte krykker i svangerskapet, var både akutt og planlagt keisersnitt assosiert med alvorlig grad av bekkenleddsyndrom. Vaginal forløsning med vakuum eller tang var også assosiert med økt risiko for bekkenleddsyndrom.
Ved rådgivning om fødselsmetode for kvinner med sterke bekkenleddsmerter i svangerskapet bør klinikere være seg bevisst at keisersnitt kan øke risikoen for sterke vedvarende smerter etter fødsel. Vår studie tyder på at der det ikke foreligger medisinske grunner til keisersnitt, er vaginal fødsel det tryggeste alternativet for kvinner med sterke bekkenleddsmerter.

Malin Eberhard-Gran

Elisabeth K. Bjelland

Nasjonalt folkehelseinstitutt

Litteratur

1. Bjelland EK, Stuge B, Vangen S et al. Mode of delivery and persistence of pelvic girdle syndrome 6 months postpartum. Am J Obstet Gynecol 2013; 208: e1-7. 